УДК 9(47)13, ББК 63.3(2)42, DOI https://doi.org/10.21638/11701/spbu19.2019.202

K. Parppei

\title{
IMAGE STUDIES \\ IN EXAMINING SHARED PERCEPTIONS OF THE PAST: \\ TWO RUSSIAN CASES
}

\section{INTRODUCTION}

Image studies have been carried out for decades in fields such as social psychology, international relations, geography - and cultural history. In the context of the latter an image is an abstract concept, referring to an idea or conception formed of some object in a human mind. These «mental images» are formed in subconscious and together they can be said to form a person's subjective information of the reality. This can be called a worldview, or a kind of mental map to navigate in the world ${ }^{1}$. They are subjective, for they never reflect the reality as such; instead, the information received gets filtered through the person's previous images, experiences, emotions and beliefs, to form an image. Images formed in human mind may be defined as simplifications of reality. They help to arrange and sort new information and thus assist the person in everyday decision-making ${ }^{2}$.

Mental images tend to be hard to change, which is partly due to their subconscious nature. Once an image is formed in a person's mind, he or she is generally more prone to accept information that supports it, rather than confronts it. This applies especially to images of objects that are not a part of the person's everyday life. For example, the mental image formed of some distant ethnic group tends to be sketchy and prone to stereotyping ${ }^{3}$.

What historians find interesting is the collective dimension of mental images. As members of a society, people share certain perceptions, conceptions, ideas and traditions. Shared images can be said to be a part of this intellectual, or cultural, heritage. They do not, obviously, appear out of nowhere, or get distributed amongst the members of the society on their own. There-

${ }^{1}$ Fält $O$. Introduction // Looking at the Other. Historical of Images in Theory and Practice / Ed. by K. Alenius, O. K. Fält and S. Jalagin. Oulu, 2007. P. 10; Ratz D. The Study of Historical Images // Faravid. 2007. Nr 31. P. 210.

${ }^{2}$ Ratz D. The Study of Historical Images... P. 200.

${ }^{3}$ Ratz D. The Study of Historical Images... P. 215.

(C) K. Parppei, 2019 
fore, instead of the object that the image is formed about, it is the processes of production, consolidation and maintenance of shared images that historical image studies are aiming to trace and analyze. As Olavi K. Fält has put it: «Historical image research draws attention to what an image is like, how we have formed a particular image of a certain thing, why we have this image, what purpose it serves, what changes have taken place in it, and what all this tells us of the creators of the image» ${ }^{4}$.

Producing and maintaining shared images has been firmly intertwined with issues of power. Most often, it is in the interests of some agent to produce, sustain and spread certain images. In the case of the most prominent images, that agent has been a part of the power structures of the given society. For instance, school textbooks are amongst the most efficient methods for indoctrinating shared images of, say, national past, for images formed in childhood tend to be the most persistent ones ${ }^{5}$. In most cases the production of textbooks has been regulated and steered by the representatives of the said power structures. The same holds largely true to public media ${ }^{6}$.

Historical image studies have been applied successfully, for instance, to representations of «otherness». Examining shared images of others - from neighbors to distant ethnic groups - can be very illuminating in the context of societies' self-images, because collective identities practically always form in relation to those who do not belong to the group or society in question?

National narratives can be said to be mentally illustrated by strong, shared images of, for instance, famous battles and heroic or saintly figures of the past. Jan Assmann has brought these images under the concept of cultural memory, announcing that it «comprises that body of reusable texts, images, and rituals specific to each society in each epoch, whose "cultivation" serves to stabilize and convey that society's self-image. Upon such collective knowledge, for the most part (but not exclusively) of the past, each group bases its awareness of unity and particularity ${ }^{8}$.

Cultural memory and collective memory — ingenious concepts as such — have been lavishly used in exploring and conceptualizing collective identities. Perhaps even too lavishly, according to critics. For instance, David Lowenthal has suggested that memory and history should be examined separately. According to him, memory is connected to experiences of an individual, whilst knowledge of history is produced and shared collectively. Representations of the past cover longer periods than individual memory, and institutions are often involved in producing and maintaining them?

Duncan S. A. Bell, too, has criticised the sloppy use of «memory» when referring to ideas of a nation's collective past, for we cannot remember something we have not experienced. He argues that «number of different though interpenetrating social and cognitive processes

${ }^{4}$ Fält O. Introduction... P. 9.

${ }^{5}$ Boulding K. The Image. New York, 1959. P. 56, 68.

${ }^{6}$ Fält O. Introduction... P. 9-10.

${ }^{7}$ Ratz D. The Study of Historical Images... P. 214; Beller M. Perception, Image, Imagology // Imagology - The cultural construction and literary representations of national characters / Ed. by M. Beller and J. Leerssen. Amsterdam, 2007. P. 4-7.

${ }^{8}$ Assmann J. Collective Memory and Cultural Identity // New German Critique. 1995. No. 65 (Spring-Summer). P. 132.

${ }^{9}$ Lowenthal D. The Past is a Foreign Country. Cambridge, 1985. P. 212-214. 
are conflated when painted with the broad brushstrokes of 'collective memory'». According to him, our shared ways to understand, conceptualize and represent events that we considered significant for our collective identities are mythical rather than mnemonic. He has coined the concept mythscape to describe «the discursive realm, constituted by and through temporal and spatial dimensions, in which the myths of the nation are forged, transmitted, reconstructed and negotiated constantly» ${ }^{10}$.

Therefore, whenever examining national narratives, we are involved with questions of mythmaking, intertwined with power structures. Image studies offer a practical methodological tool for sorting and analyzing these shared ideas and myths of the collective past. Focusing on the formation process of collective mental images connected to a certain figure, place or event that is considered important in the context of a society's past helps to - figuratively speaking - unravel the setting of perceptions into analyzable details and claims. I have chosen to use concept imagery to refer to that setting of perceptions, or body of images, connected to a certain issue. Developments and layers of meanings attached to those details and claims can then be traced, contextualized, and finally examined as a whole again.

Further, image studies give tools to operate on the multidimensional relationship between the producers and consumers of the mental apparatus of national myths and narratives. As noted above, the production (and at least to some extent, maintenance) of the most prominent shared images is usually influenced by the contemporary power structures. The primary research subject is, therefore, the producer of the image, not its object, or even the assimilators of the image ${ }^{11}$. However, the assumed distribution of the image has to be taken into account by the researcher.

The above applies especially to examination of time periods after the emergence of so called mass media from the $19^{\text {th }}$ century onwards, producing «mass images»; perceptions shared by a relatively large group of people from all layers of society. Examining earlier sources brings in another set of issues to be considered. For example, in the Middle Ages the access to textual material was limited to literate people, represented mostly by ecclesiastic circles - which, quite exclusively, were also responsible of producing the texts. So called «elite images» produced and maintained by these circles - as opposed to mass images - cannot therefore be generalized to apply to the society as a whole (in some cases, though, pictorial representations of mostly religious themes on church walls mediated some ideas and perceptions of the power structures to the illiterate people) $)^{12}$.

In order to examine the production process and producers of shared images, historians who wish to apply image research in their own work have to choose their source material according to the contemporary availability. It means gathering and studying sources that can be assumed to have had a relatively wide distribution and thus affected the shared images of their audience. Therefore, an open-minded attitude towards sources is called for. For instance,

${ }^{10}$ Bell D. Mythscapes: memory, mythology, and national identities // British Journal of Sociology. 2003. Vol. 54. No 1 (March). P. 66-65, 71-76. - Bell defines nationalist myth «as a story that simplifies, dramatizes and selectively narrates the story of a nation's past and its place in the world, its historical eschatology: a story that elucidates its contemporary meaning through (re)constructing its past» (Bell D. Mythscapes... P. 75).

${ }^{11}$ Fält $O$. Introduction... P. 9.

${ }^{12}$ See, e. g.: Ratz D. The Study of Historical Images... P. 218-220. 
popular prints, novels, poems, plays and concrete images are often valuable material for studying shared images ${ }^{13}$.

This kind of heterogenic set of sources presents the researcher with certain problems and questions. For example, how can one define the causalities and mutual influence between sources? Was, say, an oral folk poem a basis for a later compilation of an «official» image, or was the poem inspired by a textbook or some other source produced from above, so to say?

Certain epistemological problems have to be taken into account as well. First, as David Ratz puts it, examining the mind and mentality of the people of the past produces subjective information; it is one more step removed from the objective reality, when compared, for instance, «factual information» collected from documents and other written sources ${ }^{14}$. Also, historians, as products of their own time, inevitably bring along their personal images, perceptions and meanings into the research process. Researchers equipped with this contemporary mental heritage of their own represent yet another interpretative filter between the objective reality and the readers of the research ${ }^{15}$.

The structure of this essay is not that of a conventional academic article. In the following chapters two case studies, recently published by the author in form of monographs, are shortly presented in their methodological context, probing the applicability of image research shortly presented above - to the development of the perceptions concerning the collective past and, ultimately, national narratives. Both cases deal with Russian national historiography, and they illustrate the process of formation, consolidation and distribution of shared images about history ${ }^{16}$.

The first case is about the formation of the imagery concerning the early history of a Russian Orthodox monastery of Valaam. The context is primarily the spatial dimension in relation to temporal one; it examines how for a place was written a «proper» past, and how the images created were incorporated in the national narrative in formation, that is, in the shared imagery of the nation's collective past.

In the second case, the development of the images concerning the battle of Kulikovo (1380), collective perceptions of an event and its roles and functions in the imag(in)ed continuum of the national past are examined. Nevertheless, the spatial aspect is relevant in this case, too, for a battle takes place in spatial dimension, and also the question of the concrete battle site can reflect numerous contemporary issues.

\section{Case 1: The Monastery of ValaAm}

The Orthodox monastery of Valaam, located in Northwestern Russia on an island of Lake Ladoga, has developed into a popular attraction for thousands of pilgrims and tourists after the collapse of the Soviet Union. Generous donations from Russia and abroad have paved the way to the successful reconstruction of the monastery.

When examining the current situation of the monastery from the viewpoint of image studies, in its publicity Valaam relies on its image as «Northern Athos» with ancient roots, its history

${ }^{13}$ Fält $O$. Introduction... P. 10.

${ }^{14}$ Ratz D. The Study of Historical Images... P. 197-198.

${ }^{15}$ Ratz D. The Study of Historical Images... P. 198.

${ }^{16}$ Parppei K. 1) «The Oldest One in Russia» — The Formation of the Historiographical Image of Valaam Monastery. Leiden, 2011; 2) The Battle of Kulikovo Refought — «The First National Feat». Leiden, 2017. 
reaching all the way to the Christianization of Rus'. In popular historical books printed during the first decades of the $21^{\text {st }}$ century, as well as in the monastery's official internet site, it is described how «according to tradition», Apostle Andrew visited the island of Valaam, by then inhabited by pagans who worshipped Slavic gods. Later on, during the $10^{\text {th }}$ century, Greek monks Sergey and German founded a monastic site on the island (another option considered is German having been a local inhabitant converted by Sergey). Further, according to these representations, numerous other venerated saintly figures lived in Valaam prior to moving on to found monasteries of their own ${ }^{17}$.

In addition, Valaam's troublesome location in the borderland is paid attention to. For instance - «according to tradition» - a Swedish king Magnus suffered a shipwreck in Ladoga in 1371 and was stranded on Valaam. He became a monk, died shortly after and was buried in the monastery, in which his alleged grave is shown to visitors even today ${ }^{18}$.

What is interesting, though, is the lack of sources concerning the early history of the monastery. Valaam was - most probably - founded at the turn of the $15^{\text {th }}$ century. It was deserted in the beginning of the $17^{\text {th }}$ century, when the area of Ladoga became a part of Sweden. A century later it was re-founded due to the area being returned to Russia.

Only a few fragments of textual information have been preserved of the phases of medieval Valaam, and even they are vague and contradictory ${ }^{19}$. The current popular perceptions of Valaam's past have therefore not been based on actual historical sources. The obvious questions follow this discovery: what kind of process(es) created these enthralling, colourful and detailed images of the monastery's ancient history? Who produced them, when and why? How was the imagery established, maintained and distributed?

\section{SKETCHING THE IMAGE}

When we begin to trace the central claims concerning Valaam's early history backwards, we soon note that all of them can be found in the $19^{\text {th }}$ century popular historical works some of which have actually been reprinted in post-Soviet time. The $19^{\text {th }}$ century imagery was recreated, or rather, re-utilised as such, during the revival of the monastery.

It seems that the re-foundation of the monastery in the beginning of the $18^{\text {th }}$ century was in accordance with the interests of the state ruled by Tsar Peter I (1672-1725): Valaam was located near to the new capital Saint Petersburg, and its revival became a part of certain «mental fortification» of the frontier area prone to conflicts ${ }^{20}$.

Valaam's symbolic significance was indicated by the fact that during the $18^{\text {th }}$ century both secular and ecclesiastic leaders were interested in its development. Nevertheless, that development was slow and tedious. One of the problems was the lack of information concerning the initial founding and founders of the monastery. Practically only their names and

\footnotetext{
${ }^{17}$ See, for instance: The Official Site of Valaam Monastery (URL: https://valaam.ru/heritage/ (last visited - July 8, 2019)).

${ }^{18}$ Ibid.

${ }^{19}$ In the 1980s, a «new» narrative source was found and dated to the $1550 \mathrm{~s}-1570$ s. The only known copy of The Tale of Valaam Monastery is the most detailed and informative source concerning Valaam's early phases, but due to its late emergence and the fact that it apparently was not known to writers sketching Valaam's history, it does not concern our topic (Охотина-Линд Н. А. Сказание о Валаамском монастыре. СПб., 1996).

${ }^{20}$ Parppei K. «The Oldest One in Russia»... P. 38-42.
} 
presumed burial site were known. Having the founders — allegedly monks called Sergey and German - listed amongst the saints of the Orthodox Church would have secured the status of Valaam and given the new settlement much-needed prestige. However, only at the turn of the $19^{\text {th }}$ century the issue concerning the founders and the early history of the monastery was being paid notable attention to ${ }^{21}$.

During the last decades of the $18^{\text {th }}$ century a revival of monasticism and ascetism took place. At the end of the century a collection of writings of church fathers - Philokalia - was translated from Greek to Slavic by the order of Metropolitan Gavriil (1770-1801). Gavriil was fond of Valaam, and the monks of the monastery took part in the translation work. Soon after that the first claims of the founders of Valaam having been Greek emerged in texts concerning Valaam. Those speculations were soon consolidated into the image of Valaam's Greek founders ${ }^{22}$.

Simultaneously, National Romanticist ideas were rising in Russia as well as in the Western Europe. The first steps of national history writing was followed by enthusiastic rummaging of vaults of churches and monasteries in search of manuscripts that could shed light on the nation's past. These attempts also added to the pressure of Valaam to find material on its history.

Newly found texts did not offer any factual information concerning the early phases of the monastery. Loosely interpreted, however, they could be used as «building material» for the imagery in formation. For example, certain $18^{\text {th }}$ century interpolations in St. Avraam of Rostov's «Life» were interpreted to suggest that Valaam monastery might have existed already in the $10^{\text {th }}$ century. Academic circles soon dismissed such a claim, but the idea was quickly absorbed in the forming imagery of Valaam's past. The suggestion that Valaam would have been older than the famous Cave Monastery of Kiev was symbolically a significant one: it linked the monastery into the narrative of the Christianization of Rus'. It is thus not surprising that this imagined connection formed an enduring part of the imagery ${ }^{23}$.

In 1781 the Holy Synod requested priests and leaders of monasteries (igumens) to deliver it all the documents and manuscripts about the past of the institutions that could be seen having «national significance». As an answer, Valaam's Igumen Nazariy (holding the post 1781-1801) sent the Synod a $16^{\text {th }}$ century version of a $15^{\text {th }}$ century Novgorodian chronicle passage. It tells about the unfortunate war campaign of Swedish king Magnus Eriksson and his ending up on a shore of a monastery after a shipwreck. The name of the monastery was not mentioned, but the igumen referred to «local tradition» according to which it would have been Valaam ${ }^{24}$.

${ }^{21}$ Онуфрий, иеродиакон (Маханов). Причал молитв уедниненных. Валаамский монастырь и его небесные покровители преподобные Сергий и Герман. СПб., 2005. С. 33-35, 54-55; Спиридонов А. М., Яровой О. А. Валаам: от апостола Андрея до игумена Иннокентия. М., 1991. C. $72-75$.

${ }^{22}$ See, e. g.: Лисовой H. Н. Восемнадцатый век в истории русского монашества // Монашество и монастыри в России XI-XX века. Исторические очерки / Под. ред. Н. В. Синицыной. М., 2002. C. 208-217; Pospielovsky D. Orthodox Church in the History of Russia. New York, 1998. P. $128-129$.

${ }^{23}$ For a summary, see: Parppei K. «The Oldest One in Russia»... P. 206-217.

${ }^{24}$ Центральный государственный исторический архив Санкт-Петербурга (далее - ЦГИА СПб). Ф. 19. Оп. 1. Д. 15323. Л. 28. - About the request of Spiritual Consistory for sending the manuscripts and other material preserved in churches and monasteries in the area of the diocese of St. Petersburg (1792). 
King Magnus Eriksson was indeed a historical figure and he did die in a shipwreck in 1377 - by the coast of Norway instead of Lake Ladoga. The text, called «The Testament of King Magnus», was a propagandist text taking a stand in contemporary borderland issues. It was widely copied in compilations up until the $16^{\text {th }}$ century. The text's connection to Valaam, however, seems to have been invented only at the end of the $18^{\text {th }}$ century.

As in the case of Avraam's «Life», the idea of Magnus ending up in Valaam was a result of hopeful thinking and liberate interpretation of existing texts. The message of the original narrative, emphasising the moral superiority of the Orthodox Church in relation to Western invaders, was as timely as ever. Quite soon a concrete «gravestone» of Magnus emerged in Valaam. During the $19^{\text {th }}$ century the story became one of the most repeated anecdote about the monastery's past. It also merged with contemporary borderland issues: in 1812 Valaam ended up as a part of autonomous Grand Duchy of Finland, which led to tension and issues to negotiate between the monastery and the Lutheran legislation of Finland.

\section{MORE COLOURS AND DETAILS}

The first decades of the $19^{\text {th }}$ century were a turning point for the development of ideas and images about Valaam's past. Quite soon, a new option emerged concerning the founders' origins: at least German, sometimes both, was suggested to have been of Slavic origin.

This idea can be traced to a certain amateur historian, Aleksandr Sulakadzev (1771-1830). In 1818, Sulakadzev had written a compilation about the history of the monastery using «medieval sources» that turned to be his own inventions ${ }^{25}$. Being an enthusiastic National Romanticist, Sulakadzev had placed an ancient Slavic state on the islands of Valaam. He also brought forth the idea of Apostle Andrew's visit on the place. Sulakadzev's ideas about Valaam's past were soon proved to be his own inventions. However, they were soon seamlessly merged into the shared imagery in formation labeled as «monastery's tradition».

In 1819 Tsar Alexander I (1777-1825) visited Valaam. The much-anticipated event finally led to the inclusion of Sergey and German in the calendar of Russian Orthodox saints. Now the image and status of the founder saints could be consolidated in the context of official sainthood. The visit of the tsar also launched the development of the monastery conveniently located close to St. Petersburg — into a popular destination of the members of imperial family ${ }^{26}$.

During the $19^{\text {th }}$ century an impressive group of other monastic founders and local saints were connected to Valaam; in the texts concerning the monastery's past it is explained how they lived in Valaam prior to moving on to found monastic sites of their own. This «saintly pantheon» of the monastery kept growing until the latter half of the century. In most cases the background information about the saint was purely anecdotal or nonexistent. Instead, it was firmly in the interests of the monastery to consolidate its connections to surrounding areas,

${ }^{25}$ Archive of the Finnish Monastery of Valamo (далеe - AOFMOV). XII: 360, 360a, 360b. Опыт древней и новой летописи Валаамского монастыря. - Sulakadzev followed a Western European trend; the numerous attempts to forge textual material in order to add more colour and impressive stories to a nation's past.

${ }_{26}^{26}$ РГИА (далее - Российский государственный исторический архив). Ф. 797. Оп. 2. Д. 7804. Л. 8. About the veneration of Sergei and German and publication of their service et. al. (1819-1823); Государь император Александр I на Валааме, в августе 1819 года. Царское Село, 1858. С. 5-21; Онуфрий, иеродиакон (Маханов). Причал молитв уединенных... С. 611-612. 
and the image of the network of regional saints was serving these goals. Valaam even ordered an icon representing an impressive group of $\langle\text { Karelian saints }\rangle^{27}$.

\section{SHARED IMAGERY OF VALAAM's PAST}

It can be said that the basic features of the imagery of Valaam's past were established by the $1850 \mathrm{~s}$, with the active contribution of the leaders of the monastery, supported by the ecclesiastic as well as secular power structures, and catalysed by the general interest in the national history. The re-established monastery desperately «needed» a history, and a suitable past was compiled using heterogenic - and sometimes quite shady - material in a liberal way.

What can we say about the process of actually sharing the images? How and by whom were they distributed? The process can be called a «self-feeding circle of fame». The first decades of the $19^{\text {th }}$ century witnessed a general rise in the interest towards pilgrimages and tourism, as well as travel writing. A growing number of visitors arrived in Valaam and some of them chose to write and publish a story of their visit in a newspaper or a journal afterwards, or even write a whole book about it. In these numerous articles and publications, the ideas of Valaam's past - originally formulated in the monastery and circulated in textual form mostly amongst ecclesiastics and officials, and orally amongst visitors - were being gradually distributed to larger audience.

In 1850 s, a steamship connection was established between St. Petersburg and Valaam. This event greatly boosted the development of the monastery into a popular destination for pilgrims and tourists - and a growing number of writers and artists, who in their turn created and consolidated images of the idyllic island monastery.

During the 1860 s, the monastery started its own publishing activities, which can be seen as yet another turning point in the establishment of the shared imagery concerning Valaam's past. In 1864 a book called «Monastery of Valaam» was published. It was written by a censor from St. Petersburg, N. V. Elagin, with the permission of the monastery. The book, which became very popular and was reprinted numerous times, was a colourful and detailed combination of geography, history and spiritual significance of Valaam. Sulakadzev's ideas had a prominent role in the history section, which notably contributed to their consolidation in the shared imagery of the monastery's early phases ${ }^{28}$.

Paradoxically, it was exactly the scarcity of «factual» information concerning Valaam's history that offered a kind of tabula rasa, a clean canvas on which to produce colourful images about the honorary past of the monastery. Orthodox Christian tradition with its hagiographic texts further justified the usage of heterogenic material, as far as it supported the general idea of medieval Valaam's significance as a spiritual center. Pleading to «monastery's tradition» was also a convenient way to merge very diverse material into the histori(ographi)cal imagery.

The images supporting Valaam's honorary past — being at first of speculative nature — were produced in order to justify and support the re-foundation and revival of the monastery, and they soon became intertwined with National Romanticist ideas and national history writing. The images of Valaam as the oldest monastery of Russia, the ancient Slavic background of the site and the monastery as a spiritual outpost in the frontier area were during the $19^{\text {th }}$ century

${ }^{27}$ About the formation of this «saintly pantheon» of Valaam in detail, see: Parppei K. «The Oldest One in Russia»... P. 178-237.

${ }^{28}$ Parppei K. «The Oldest One in Russia»... P. 69-79. 
anchored in the developing continuum of national past of the Russian Empire. This added to their allure amongst pilgrims, visitors and the reading audience. The durability of shared images once formed is indicated by the fact that exactly the same imagery was entirely «usable» after the Soviet period and revival of the monastery once again.

\section{Case 2: The Battle of Kulikovo}

The battle of Kulikovo was allegedly fought in 1380 in the area of present Tula, near River Don, between the troops of Muscovite Grand Prince Dmitriy Ivanovich and Tatar Emir Mamay. The event, resulting in the victory of the Muscovite troops, has been represented as a crucial turning point in Russian history. Its significance is based on two main claims. First, it has been seen as the prologue for the final liberation of the Russians of the so called «Tatar yoke», referring to the period of Mongol/Tatar rule over the area of Rus' from 1223 to 1480. Second, according to Russian national historiography, the victory earned Moscow the status of the leading principality in the area of Rus', the ultimate result of which was the unification of the Russian lands.

For example, this is how a school text book on Russian history, published in 2013, describes the consequences of the battle: «After the battle of Kulikovo, the long-time assault of Asia on Europe was to a significant extent halted. Indeed, soon Rus' began to attack and the Horde to defend itself. [Also] the battle of Kulikovo demonstrated that Moscow had become the voice of all-Russian national interests and the true leader in the unification and liberation of Rus'. The Muscovite prince went down in history with the name Dmitriy Donskoy» ${ }^{29}$.

As in the case of Valaam, certain «layers of meanings» can be traced when following the formation of the imagery concerning the battle to its roots. The first layers of representations affecting the formation process are of earlier origin than in Valaam's case; they definitely belong to the sphere of «elite images» with no collective dimension. However, the images created by the scribes during the $15^{\text {th }}$ and $16^{\text {th }}$ centuries form the essential kernel around of which new layers of meanings were attached during the following centuries, the medieval imagery gradually developing into «mass images», truly collective perceptions, of the event ${ }^{30}$.

${ }^{29}$ Сахаров А. Н. История России с древнейших времен до конца XVI века. Академический
школьный учебник. М., 2013. С. 142 .
${ }^{30}$ Traditionally, in Russian scholarship the textual sources concerning the battle have been
examined from the viewpoint of «factual» history, aiming to reconstruct the events. The literary
and cultural historical approach has been constantly and successfully applied as well (for instance,
a versatile collection of articles, called Куликовская битва в литературе и искусстве / Под
ред. О. А. Державиной, А. Н. Робинсона (Москва, 1980). However, a certain paradigmatic
shift has taken place during the last decade. For instance, A. O. Amel'kin and Yu. V. Seleznev in
their book (Амелькин А. О., Селезнев Ю. В. Куликовская битва в свидетельствах coвремен-
ников и памяти потомков» (Москва, 2011)) meticulously follow the development of the ideas
соnсеrning the battle in Russian historiography. Another book: Азбелев C. Н. Куликовская победа
в народной памяти (СПб., 2011), in its turn, examines the relationship between textual and oral
tradition concerning the battle. Nevertheless, despite of the notable scholarly merits of these books
(both were also used as reference literature for the monograph this article's second case study
is based on), they do not critically examine the position or the layers of meanings of the battle
in the imagery of the national past, but rather, take its established significance in the national
narrative as such. Some recent publications, such as article Pocmoвцев E. А., Сосниций Д. А. 


\section{Alliance of Moscow and the Church}

Historians - mostly Russian and Soviet ones - examining the battle of Kulikovo have traditionally approached the medieval accounts of the event in order to find information of how the events proceeded. However, certain features of medieval text production makes the approach problematic. The understanding of what is «reliable» factual material has remarkably changed over centuries. For instance, in medieval thinking, truth was eternal, but it was gradually revealed to people according to a divine plan. Consequently, it was perfectly acceptable to update texts according to «new» information - for instance, a changed political situation that demanded a new viewpoint on past events. Adding and removing details while copying the texts was, in this light, perfectly acceptable ${ }^{31}$.

Also, texts were written according to certain rhetoric rules. Hagiographies - lifes of saints are a good example: they were supposed to be an example of pious life, and certain features had to be included accordingly. In a similar way, certain features belonged to a rhetorically acceptable battle account - for instance, biblical references were common (this, of course, held true for medieval text production in general, too, for the Bible was the ultimate yardstick to measure reality). Details and whole sections were sometimes borrowed from previous texts of similar nature and attached to the one in progress ${ }^{32}$. Also, depictions of historical conflicts are practically always representations of «us» and «them». In medieval texts this binary culminates in a very dualistic way, especially in accounts of hostile encounters between Christian and non-Christian peoples ${ }^{33}$.

Whilst these features of medieval textual sources complicate the search for historical facts, they actually can be seen as a benefit for an image researcher. Stereotypical presentation and rhetorical regulations actually produced those simplifications of reality, which are the very subjects of image research ${ }^{34}$.

The first accounts of the battle of Kulikovo - found in chronicle entries written in 1440s - are quite short and laconic simply noting that the Muscovite prince fought Tatar troops led by Mamai, and won the battle by the mercy of $\operatorname{God}^{35}$. The emergence of the texts

“Куликовский плен”: образ Дмитрия Донского в национальной исторической памяти» // Quaestio Rossica. 2017. Т. 5. № 4. C. 1149-1163 aim to meet this challenge in their approach, too. ${ }^{31}$ See, for instance: Picchio R. The Impact of Ecclesiastic Culture on Old Russian Literary Techniques // Medieval Russian Culture / Ed. by H. Birnbaum and M. S. Flier. Berkeley, 1984. P. 266; Ingham N. On Historical Truth and Hagiographical Truth: Saint Feodosii's Mother // Russian History/Histoire Russe. Vol. 18. No. 2 (Summer 1991). P. 128-131.

${ }^{32}$ See, for instance: Heffernan T. Sacred Biography. Saints and their Biographers in the Middle Ages. New York, 1988. P. 5-6; Picchio R. The Impact of Ecclesiastic Culture... P. 287.

${ }_{33}$ See, for instance: Hoppenbrouwers $P$. Medieval peoples imagined // Imagology — The cultural construction and literary representations of national characters / Ed. by M. Beller and J. Leerssen. Amsterdam, 2007. P. 58; Lotman Yu. M., Uspenskiy B. A. The Role of Dual Models in the Dynamics of Russian Culture (Up to the Eighteenth Century) // Semiotics of Russian Culture / Ed. by Yu. M. Lotman and B. A. Uspenskii. Ann Arbor, 1984. P. 3-35.

${ }^{34} \mathrm{Mäki}$-Petäys M. On the Applicability of Image Research to the Study of Medieval Hagiographies // Looking at the Other. Historical of Images in Theory and Practice / Ed. by K. Alenius, O. K. Fält and S. Jalagin. Oulu, 2007. P. 91.

${ }_{35}$ Printed and edited versions of most of these accounts can be found in: Рыбаков Б. А., Кучкин В. А. Памятники Куликовского битва. СПб., 1998. — In the same publication, the dating of each redaction and copy is presented. Extensive literature on the dating of the early texts has 
concerning Kulikovo battle may have had a political catalyst: the contemporary problems with Tatars. Similarly, the new «wave» of battle accounts in 1480s may have been connected to contemporary political situation ${ }^{36}$. The latter cluster of texts was already notably lengthened and fattened with details when compared to the previous ones.

However, it was only during the first half of the $16^{\text {th }}$ century when the Kulikovo battle began to be represented a truly significant event. By then Moscow had gained a dominant position amongst the Russian principalities, and the literary production - carried out in ecclesiastic circles - had been harnessed to support the claimed legitimacy of its superiority. In practice, many texts had been «updated» to promote Moscow's leading role ${ }^{37}$.

A lengthy and much copied text called The Tale of the Rout of Mamai was the foundation for the formation of the established imagery concerning the battle of Kulikovo. It emphatically underlined the cooperation of Moscow and the Church in fighting the infidels, as well as Moscow's leadership amongst the other principalities. For instance, in the text the other Russian princes are repeatedly depicted as willing to give their lives for the Muscovite Grand Prince and the Church; they even compare themselves to sheep and Dmitriy to a shepherd ${ }^{38}$.

Compared to the previous accounts of the battle, The Tale includes also an array of other new and colourful scenes, details, figures and dialogues, all of them supporting the aforementioned main ideas, and also reflecting political issues of the first decades of the $16^{\text {th }}$ century. Some of these details became popular and constantly reproduced in all kinds of later depictions, both textual and pictorial.

For example, a much reproduced scene of Grand Prince Dmitriy Donskoy meeting the Igumen Sergey of Trinity Monastery and receiving blessing prior to the battle from the saintly elder, first appeared in The Tale ${ }^{39}$. It is also described how Sergey gave Dmitriy two warrior monks to be included in the troops, the other one of which fought in a symbolically significant duel with a fiery Tatar, and perished ${ }^{40}$. These scenes symbolized the cooperation between the Orthodox Church and secular rulers. The duel was an impressive metaphor of the battle between Christianity and Islam, which explains its later applicability and popularity in the representations of the battle.

been published over decades and it is not practical to go through the issue in this context; for some contributions on the discussion see, for instance: Бобров А. Г. Новгородские летописи XV века. СПб., 2001; Halperin C. Text and Textology: Salmina's dating of the Chronicle Tales about Dmitry Donskoy // Slavonic and East European Review. 2001. Vol. 79. No. 2. P. 248-263; Салмина М. А. К вопросу о времени и обстоятельствах создания «Сказания о Мамаевом побоище» // ТОДРЛ. T. 56. 2004. C. 251-274. - See also: Амелькин А. О., Селезнев Ю. В. Куликовская битва в свидетельствах современников и памяти потомков. М., 2011. С. 266-320.

${ }^{36}$ Ostrowski D. Muscovy and the Mongols. Cross-Cultural Influences on the Steppe Frontier. Cambridge, 2002. P. 159-160.

${ }^{37}$ See, e. g.: Picchio R. The Impact of Ecclesiastic Culture... P. 251-252; Crummey R. The Formation of Muscovy 1304-1613. London, 1987. P. 192-200.

${ }^{38}$ Сказание о Мамаевом побоище (вариант Ундольского) // Памятники Куликовского цикла. СПб., 1998. С. 148, 176.

${ }^{39}$ Сказание о Мамаевом побоище... Р. 149-151.

${ }^{40}$ Сказание о Мамаевом побоище... P. 151-152. - On the multifaceted figure of Igumen Sergey, see, for instance: Miller D. Saint Sergius of Radonezh, His Trinity Monastery, and the Formation of the Russian Identity. DeKalb, 2010. 
In the 1550-1560s two massive compilations were written, both celebrating the historical and divine roots of Muscovite power. These compilations, called the Book of Degrees of the Royal Genealogy and Nikon Chronicle, further consolidated the status of the battle of Kulikovo, emphasised the role of the Church in the events and turned the battle from a single event to a crucial knot in the continuum of the collective past. The events were depicted according to the already established plot-structure, but for the first time the imagery had a historical context - or rather, mythistorical context ${ }^{41}$.

In the Book of Degrees, produced in Ivan IV's (1533-1584) scriptorium, the battle is also strongly connected to the struggle between Christianity and Islam, reflecting the conquest of the khanate of Kazan in 1552 by Ivan. Dmitriy Ivanovich was, for the first time, honored with the epithet «Donskoy», which paired him with another warrior prince, Aleksandr Nevskiy. Dmitriy was depicted as a defender of the fatherland against eastern threat, while Aleksandr was presented having warded of western invaders ${ }^{42}$.

\section{TOWARDS A SHARED NATIONAL IMAGERY}

Despite the emergence of new contexts and layers of meanings, the images concerning the battle of Kulikovo were produced, reproduced and consumed by the same «elite» circles well until the end of the $17^{\text {th }}$ century, and even further. The gradual transfer of the Kulikovo accounts from manuscripts to the age of print grounded the emergence of truly shared perceptions concerning the event.

An important step towards shared imagery was taken when The Tale of the Rout of Mamai was included in the third edition of so called Kievan Synopsis in 1681. The book was produced in Kievan Cave Monastery, and it can be said to have presented a «slavo-Rossian» viewpoint on the issue. The monks of the monastery were concerned about the Islamic and Catholic pressure, which led them to emphasize the superiority of Muscovite leaders instead ${ }^{43}$. The Kievan Synopsis was reprinted all the way to the mid-19 $9^{\text {th }}$ century, and it was widely used as a textbook ${ }^{44}$.

During the $18^{\text {th }}$ and $19^{\text {th }}$ centuries and the rise of national history writing, the imagery concerning the battle of Kulikovo was consolidated in the context of the nation's past. In the scholarly works of the late $18^{\text {th }}$ and early $19^{\text {th }}$ century the context of the battle gradually shifted

${ }^{41}$ For a summary, see: Parppei K. The Battle of Kulikovo Refought... P. 87-94. - On the ideological background of these $16^{\text {th }}$ compilations, see, for instance: Клосс Б. М. Никоновский свод и русские летописи XVI-XVII веков. М., 1980; Lenhoff G. Politics and Form in the Stepennaia Kniga // The Book of Royal Degrees and the Genesis of Russian Historical Consciousness / Ed. by G. Lenhoff and A. Kleimola. Bloomington, 2011. P. 157-174; Miller D. Creating Legitimacy: Ritual, Ideology, and Power in Sixteenth Century Russia // Russian History/ Histoire Russe. Vol. 21. No. 3 (Fall 1994). P. 289-315.

${ }^{42}$ Степенная книга, степень XII // Степенная книга царского родословия по древнейшим спискам. Тексты и комментарии. Т. II. М., 2012. С. 65-66.

${ }^{43}$ See, for instance: Plokhy S. The Origins of the Slavic Nations. Premodern Identities in Russia, Ukraine, and Belarus. Cambridge, 2006. P. 259-261.

${ }^{44}$ The plot structure established in The Tale of the Rout of Mamai was replicated in the Synopsis with some minor $17^{\text {th }}$ century extrapolations; this inclusion neatly transferred the $16^{\text {th }}$ century narrative to the age of print (Пушкарев Л. Н., Сидорова Л. П. Повести о Куликовской битве в русской лубочной картинке и книжке XIX - начала XX века // Куликовская битва в литературе и искусстве. М., 1980. С. 129-130). 
from religious to political one. Especially after the Napoleonic wars the event was represented as the first national and collective military effort in Russian history. This view - a profoundly anachronistic one! - was enthusiastically expressed by N. M. Karamzin (1766-1826) in his massive work History of the Russian State. He described, for instance, how the Russian people were «awakened from a deep slumber» and how «everybody wanted to serve the fatherland, some with swords, others with prayers and Christian deeds $\rangle^{45}$. Later on, V. O Kliuchevskiy (1841-1911) called the events on the field of Kulikovo «the first national victory» ${ }^{46}$. This viewpoint emphasised the significance of the battle in the context of the (imagined) continuum of national past, already sketched in the Book of Degrees, with one event neatly leading to another, forming coherent and comprehensible developments.

Along with the rise of nationalistic ideas, the question of Russia's geopolitical and cultural position became acute, bringing into discourse the issue of the Europe and $\mathrm{Asia}^{47}$. The battle of Kulikovo, too, began to symbolise not just the efforts of Russian against Tatar invaders, but the fight for dominance between these two spheres. This new layer of meanings was explicitly formulated by S. M. Solovyev (1820-1879), who announced that the victory of Kulikovo was «a sign of triumph of Europe over Asia»"

These compilations of Russian history were not yet very widely distributed outside the academic circles, but the development of printing practices and general literacy during the $19^{\text {th }}$ century created a foundation for the formation of truly shared images of the past. Numerous popular publications inspired by the battle of Kulikovo emerged during the century, based on the scholarly works on national history. The range of these publications varied from semi-scholarly military-historical works, equipped with references and maps, to colourful and emotional fictional stories inspired by the battle accounts ${ }^{49}$. They mainly reproduced, consolidated and - most importantly - distributed the existing imagery and plot-structure concerning the battle.

When it comes to the context of the battle certain new developments took place. Whilst the battle had previously been used to refer to the competitive setting between Christianity and Islam (or, further, Europe and Asia), it was now applied to different kinds of contemporary conflicts. For instance, the Napoleonic Wars inspired National Romanticist writers to compare the deeds of Tsar Alexander I to those of his predecessors, including Grand Prince Dmitriy. A play called Dmitriy Donskoy had been written by V. Ozerov (1769-1816), and received with patriotic enthusiasm in $1807^{50}$. In a work published in 1827, A. V. Kazadaev (1781-1854) announced about Alexander and Dmitriy that the «two men of those periods are also very alike; both were significant afflicted heroes, both served until the feast of victory ${ }^{51}$.

${ }_{45}$ Карамзин Н. М. История государства российского. Кн. II (Т. V, VI, VII, VIII). СПб., 1842. C. 35-36.

${ }^{46}$ Ключевский В. О. Русская история. Полный курс лекций. Кн. І. Минск, 2007. С. 376.

${ }^{47}$ Bassin M. Asia // The Cambridge Companion to Modern Russian Culture / Ed. by N. Rzhevsky. Cambridge, 2014. P. 65-93.

${ }^{48}$ Соловьев С. М. История России с древнейших времен. Кн. II // Соловьев С. М. Сочинения в восемнадцати книгах. М., 1988. С. 278. On Kulikovo battle in Russian imperial historiography in also: Амелькин А. О., Селезнев Ю. В. Куликовская битва... С. 320-356.

${ }^{49}$ For a summary and further examples, see: Parppei $K$. The Battle of Kulikovo Refought... P. 137-161.

${ }^{50}$ Озеров В. А. Димитрий Донской // Сочинения В. А. Озерова. СПб., 1807.

${ }^{51}$ Казадаев А. В. Историческое похвальное слово Димитрию Донскому. СПб., 1827. С. 125. 
During the 1880-90s the amount of popular publications concerning the battle of Kulikovo peaked, catalysed by the 500 years anniversary of the event. The efforts of Russian Empire to assist Serbia and Bulgaria under the Ottoman rule in 1870s were also reflected in some of the texts, once again emphasizing the Slavic Orthodox resistance towards Islam ${ }^{52}$. Thus the battle of Kulikovo served as a convenient «template» for further hostile encounters with any Islamic enemies.

\section{«CONTEMPORARY KULIKOVO FIELDS»}

School textbooks on national history have been an especially effective device in distributing the images and perceptions concerning the collective past. During the $19^{\text {th }}$ century, basic schooling in Russia was arranged by several organisations. Certain curriculum guidelines were drawn by the state and the Church officials. On the curricula on teaching history, the battle of Kulikovo was often explicitly mentioned ${ }^{53}$.

In the textbooks, the established imagery and plot-structure were faithfully reproduced, often depicted in a dramatic way that must have created strong images on pupils' minds. Details highlighting the courage of Dmitriy Donskoy and his troops were emphasised. One of them was a scene of crossing the River Don prior to the battle: the grand prince encourages his troops to move forward by saying «an honorable death is better than a miserable life» ${ }^{54}$. This emphasis may have been chosen on purpose: many of the pupils ended up in military service, and deeply imprinted images of exemplary bravery were undoubtedly seen beneficial for serving the empire.

During the $19^{\text {th }}$ century, also oral tradition concerning the battle of Kulikovo, such as stories and fairytales, were collected. Some researchers have proposed that the preserved textual sources would initially have been based on those oral accounts; however, due to their late collection period (popular textual accounts were already widely available) it is more likely that the oral versions were loosely based on textual imagery instead ${ }^{55}$.

Concrete images depicting the events connected to the Kulikovo battle emerged, too, between the $18^{\text {th }}$ and $20^{\text {th }}$ centuries. Especially scenes such as the duel between warrior monk Peresvet and the Tatar, and Dmitriy receiving a blessing from Igumen Sergey prior to the battle, were turned into paintings. Also a monument - a granite column with a cross on top - was erected in Tula region to mark the presumed site of the battle in contemporary landscape in $1850^{56}$.

During the Soviet time the imagery concerning the battle was maintained in school textbooks and other representations in its established form. In World War II it had yet another

${ }^{52}$ See, for instance: Тихомиров Е. Куликовская битва. Исторический очерк. К 500-летней годовщине Куликовской битвы (8 Сентября 1380 года - 8 Сентября 1880 года). М., 1880.

${ }^{53}$ Brooks $J$. When Russia Learned to Read. Literacy and Popular Literature, 1861-1917. Evanston, 2003. P. 35-43, 50-51.

${ }^{54}$ See, for instance: Острогорский М. Я. Учебник русской истории: Элементарный курс с рисунками, картами, таблицами и вопросами для повторения. СПб., 1898. С. 36-37.

${ }_{55}^{55}$ See, for instance: Азбелев C. Н. Куликовская победа в народной памяти. СПб., 2011. - In this article it is not possible to examine the popular presentations of the battle in detail - for instance, poetry, stories, and plays - but the author has addressed the issue in the monograph (Parppei K. The Battle of Kulikovo Refought... P. 137-214).

${ }_{56}^{5}$ See, for instance: Амелькин А. О., Селезнев Ю. В. Куликовская битва... С. 344-345. For a summary, see: Parppei K. The Battle of Kulikovo Refought... P. 203-214. 
of its «high seasons», once again proving its applicability to many situations involving external threat. A propaganda poster was printed, depicting contemporary soldiers attacking the enemy, supported by Dmitriy Donskoy and his troops in medieval harness. The sentence «Better an honorable death than a shameful life» was attached to the scene, the words depicted as a quote by Dmitriy, completed with Iosif Stalin's notion: «Let the heroic image of our great ancestors inspire you in this war» ${ }^{57}$. Already in 1939 Red Army had printed a booklet about the battle of Kulikovo, announcing the greatness of Soviet Union and calling its military challenges «contemporary Kulikovo fields» ${ }^{58}$.

Around 1980s, the new anniversary of the battle produced a huge amount of publications, seminars and events concerning the issue. In 1988, Dmitriy Donskoy was proclaimed a saint in connection with the thousandth anniversary of the Christianization of Rus'. Patriarch Kirill, in his speech in 2000, explained the background of the "canonization» by saying that «raising the level of national awareness» with regard to the battle had demanded remarkable spiritual resources, and that this had been taken into account while making the decision ${ }^{59}$.

In the post-Soviet Russia, the battle of Kulikovo has been «refought» numerous times in textbooks, popular historical works, internet discussions, and so forth. Despite of some critical voices, the established imagery of the battle and its hero, Grand Prince Dmitriy, has been reproduced quite uncompromisingly in the context of national unity and Russia's honorable history ${ }^{60}$.

\section{CONCLUSION}

These two cases, both examining the formation of historical imagery or collective perceptions concerning a certain phenomenon - a place, and an event - have certain differences as well as similarities, when probed with tools of historical image research.

Pierre Nora has noted that «memory attaches itself to sites, whereas history attaches itself into events ${ }^{61}$. The imagery of Valaam's past can indeed be seen as essentially spatial, local, and - once formed - quite stable and unchanged, also in the sphere of meanings. Its primary context has been an ecclesiastic one, and its formation has been firmly based on Orthodox monastic culture and traditions. Indeed, as noted above, «monastery's tradition» has offered a convenient explanation for many shady sketches of Valaam's past. Perhaps the idea of local tradition can here be loosely aligned with Nora's notion of memory, which also applies to

\footnotetext{
${ }^{57}$ Parppei K. The Battle of Kulikovo Refought... P. 217, 220.

${ }^{58}$ Кучин П. Куликовская битва. Библиотека красноармейца. М., 1939. С. 30.

${ }^{59}$ Rock S. Rasputin the New - Mythologies of Sanctity in Post-Soviet Russia // Nationalist myths and modern media: Contested identities in the age of globalization / Ed. by J. H. Brinks, E. Timms and S. Rock. London, 2005. P. 258-259.

${ }^{60}$ See, for instance: Ростовцев Е. А., Сосницкий Д. А. «Куликовский плен»... С. 1155-1158. The Russian national narrative and imagery concerning the battle have been challenged by, for instance, Tatar scholars, who have presented their own views on the events (on the issue see, for instance: Halperin C. A Tatar Interpretation of the Battle of Kulikovo Field, 1380: Rustam Nabiev // Nationalities Papers. 2016. Vol. 44 (1). P. 4-19; Sperling V. Making the Public Patriotic: Militarism and Anti-Militarism in Russia // Russian Nationalism and National Reassertion of Russia / Ed. by M. Laruelle. New York, 2009. P. 44-45.

${ }^{61}$ Nora P. Between Memory and History // Les Lieux de Mémoire. Representations. Vol. 26. Spring, 1989. P. 22.
} 
the distribution and maintenance of the shared imagery through collective efforts by visitors, along with the monastery's own publishing activities.

However, the formation process of the imagery of Valaam's early history had points of contact with contemporary political issues, too. Ideas such as connecting the foundation of monastery temporally to the mythical Christianisation of Rus', strongly resonated with national history writing and intertwined the history of the monastery to that of the empire, or rather, to the Russian mythscape. The same holds true to the borderland issues. The idea of contested frontier can be said to have been in the core of the formation of the imagery of the monastery located in the turbulent frontier area ${ }^{62}$.

The shared imagery formed on the battle of Kulikovo can be described, in turn, primarily - but not exclusively - temporal and national (the concept used here in contrast with local, and referring to the imagery from the $19^{\text {th }}$ century onwards) in nature. The basic plot-structure gained its established form already in the $16^{\text {th }}$ century, but the meanings have been in fluctuation. The ideas of unity and strong central power have been applicable to numerous political situations, especially any involving external threat, and they have been useful in indoctrination of large numbers of people.

Whilst the formation of the images of Valaam's past has a primarily religious and only secondarily political context — as far as these two can be separated — in the case of Kulikovo the setting can be said to be reciprocal. When it comes to the medieval context, the two were firmly intertwined, but from the $18^{\text {th }}$ century onwards the political meanings of the battle began to dominate the shared imagery.

In both cases the formation and distribution of the imagery had — and still has - the full support of power structures. This means that the idea of an ancient spiritual center on the borderland, as well as the idea of a crucial battle that steered the development of the nation, have both been aligned with the interests of power circles of each given time.

What is common for both Valaam and Kulikovo, is also the importance of Nationalistic and National Romanticist thinking in the formation and consolidation of the imageries. It established the budding idea of national history as a continuum, on which events, figures and even places could be attached to form a coherent image of the collective past.

It is important to note that the formation of this collective mythscape has been a profoundly anachronistic process. Of course, hindsight — perception of the significance of events after they have occurred - lies in the very core of history writing as such ${ }^{63}$. Especially in the case of Kulikovo this phenomenon has a central role: the idea of the medieval battle as a crucial turning point — «the first national victory» — is a prime example of explaining history in the light of contemporary knowledge and the prevailing ideological undercurrents.

In the case of Valaam, more details and colour were added to the sketch along with the rising of the monastery's contemporary status. A good example is the constant expansion

${ }^{62}$ Hastings $A$. The Construction of Nationhood. Ethnicity, Religion and Nationalism. Cambridge, 2000. P. 190-191.

${ }^{63}$ As David Lowenthal has put it: «Historical hindsight tidies chaos into order, often into predestined sequence, as though things could not have happened otherwise» (Lowenthal D. Heritage Crusade and the Spoils of History. Cambridge, 2009. P. 115). Hindsight is also connected to the issue of narrativity: how single points are arranged into coherent wholes (Topolski J. The Role of Logic and Aesthetics in Constructing Narrative Wholes in Historiography // History and Theory. 1999. Vol. 38. No 2. P. 201). 
of Valaam's «saintly pantheon»; as Valaam's fame grew, more and more local saints and monastery founders were added into the group of holy men that were said to have resided in ancient Valaam. This anachronistic process added the prestige to both Valaam and the smaller monasteries in the area of Karelia and Olonets.

Using imagological approach as a tool to examine perceptions concerning the past of a place, or a historical event, has demanded certain adaptations. In both cases, there are actually many simultaneous images that can be represented either as a whole or independently. For instance, the duel between the monk and a Tatar on the field of Kulikovo has been turned into visual art numerous times. In the same way, the story of Apostle Andrew's visit in Valaam, or the legend of King Magnus, can be reproduced separately of the other details of the foundation narrative of Valaam.

The context of these separate images, nevertheless, is the same, and the individual images can only be fully understood in the context of the whole. In the two cases examined here there are actually images in an image, which is why I have found the concept imagery useful to refer to the whole of the images; the body of collective, established perceptions concerning the issue. Applying imagological approach to these kinds of cases demands, therefore, operating on two concurrent levels. First, each separate claim and detail - the image in the image - and its formation and development has to be analysed separately: when did it emerge, by whom, in what circumstances, and so on. Second, these details have to be examined and contextualised as a whole, studying the contemporary roles and functions of the imagery at each given time.

The role of researcher has to be taken carefully into account, too. The images of the researcher tend to intertwine with those that are being studied, as noted above. While this is to some extent inevitable, one has to be aware of the issue. There is also the question of choices in defining the research topic, the time period examined, arranging the source material - thematically or chronologically — and defining the relevant context. For instance, in the research about the imagery concerning Kulikovo the division of the examined timeline into periods and categorizing of the sources are not devoid of the problems of subjectivity, hindsight or narrativity. These problems are not, of course, exclusive to historical image research, but operating on long timelines and issues concerning mind and mentality rather than more concrete information do increase the risk of the researcher's voice being heard louder in the findings, than the voice of those he or she is aiming to understand.

Nevertheless, these two case studies, very briefly presented in this article, indicate that despite of certain problems and risks - which should always be surveyed, considered and finally discussed along the research process - the imagological approach offers a worthy pragmatic tool also to operate on complex sets of established claims, ideas and images, such as national narratives, formed - or forged! - during a long time period under various circumstances.

Информация о статье

Статья подготовлена при финансовой поддержке Академии наук Финляндии, грант Academy Research Fellow.

Автор: Парппей, Кати Мари Йоханна - научный сотрудник, доцент, факультет географических и исторических исследований, Университет Восточной Финляндии, Финляндия; пожизненный член, Клэр Холл, Кембриджский университет, Великобритания, Scopus ID 36161985900, e-mail: kati.parppei@uef.fi 
Заголовок: Image Studies in Examining Shared Perceptions of the Past: Two Russian Cases [Исследования образов при изучении представлений о прошлом: два российских случая]

Резюме: Методы имагологии - исследования образов - успешно используются при изучении, например, представлений об «инаковости». Несмотря на определенные ограничения, этот подход может быть применен при анализе различных и более сложных явлений. В данной статье мы рассмотрим два тематических исследования, касающихся формирования национальных нарративов в российской историографии, и продемонстрируем возможности этого метода в изучении коллективных представлений о прошлом. Первое исследование касается формирования историографического образа пограничного Валаамского монастыря. Во втором рассматривается развитие коллективных представлений о Куликовской битве (1380 г.). Можно сказать, что при формировании образа Валаама акцент делается на пространственность, религию и спорность границ, в то время как в случае с Куликово преобладают идеи времени, национального значения и активного сопротивления. Оба образа сформированы намного позже времени события. Общим моментом выступает тот факт, что их формирование было переплетено с современными политическими проблемами. Этот процесс также получал полную поддержку со стороны власти. Кроме того, в обоих случаях ощущается сильное влияние национального романтизма. Центральную роль это явление играет в создании образа Куликовской битвы. Идея средневековой битвы как переломного момента становится ярким примером объяснения истории в свете современных знаний и преобладающих идеологических течений. В обоих случаях можно проследить формирование отдельных образов, сцен и фигур, а с другой стороны - изучить их целостное изображение.

Ключевые слова: образ, историография, национализм, идентичность, мифы, повествование

\section{Литература, использованная в статье:}

Азбелев, Сергей Николаевич. Куликовская победа в народной памяти. Санкт-Петербург: Дмитрий Буланин, 2011. $312 \mathrm{c}$.

Амелькин, Андрей Олегович; Селезнев, Юрий Васильевич. Куликовская битва в свидетельствах современников и памяти потомков. Москва: Квадрига, 2011. 414 с.

Бобров, Александр Григорьевич. Новгородские летописи XV века. Санкт-Петербург: Дмитрий Буланин, 2001. $287 \mathrm{c}$.

Клосс, Борис Михайлович. Никоновский свод и русские летописи XVI-XVII веков. Москва: Наука, 1980. $336 \mathrm{c}$.

Куликовская битва в литературе и искусстве / Отв. ред. Робинсон, Андрей Николаевич. Москва: Наука, 1980. $288 \mathrm{c}$.

Кучин, П. Куликовская битва. Библиотека красноармейца. Москва: Воениздат, 1939. 32 с.

Лисовой, Николай Николаевич. Восемнадцатый век в истории русского монашества // Монашество и монастыри в России XI-XX века. Исторические очерки / Под. ред. Синицыной, Нины Васильевны. Москва: Наука, 2002. С. 186-222.

Онуфрий, иеродиакон (Маханов). Причал молитв уедниненных. Валаамский монастырь и его небесные покровители преподобные Сергий и Герман. Санкт-Петербург: Издательство «Царское Дело», $2005.738 \mathrm{c}$.

Охотина-Линд, Наталья Александровна. Сказание о Валаамском монастыре. Санкт-Петербург: Глагол, 1996. $246 \mathrm{c}$.

Пушкарев, Лев Никитович; Сидорова, Л. П. Повести о Куликовской битве в русской лубочной картинке и книжке XIX - начала XX века // Куликовская битва в литературе и искусстве / Под ред. Робинсона, Андрея Николаевича. Москва: Наука, 1980. С. 129-153.

Ростовиев, Евгений Анатольевич; Сосницкий, Дмитрий Александрович. «Куликовский плен»: образ Дмитрия Донского в национальной исторической памяти // Quaestio Rossica. T. 5. 2017. № 4. C. 1149-1163.

Рыбаков, Борис Александрович; Кучкин, Владимир Андреевич. Памятники Куликовского цикла. СанктПетербург: Русско-балтийский информационныи центр БЛИЦ, 1998. 412 с.

Салмина, Марина Алексеевна. К вопросу о времени и обстоятельствах создания «Сказания о Мамаевом побоище» // Труды отдела древнерусской литературы. Т. 56. 2004. С. 251-274.

Спиридонов, Андрей Михайлович; Яровой, Олег Аркадьевич. Валаам: от апостола Андрея до игумена Иннокентия. Москва: Прометей, 1991. 125 с. 
Assmann, Jan. Collective Memory and Cultural Identity // New German Critique. 1995. No. 65 (SpringSummer). P. 125-133.

Bassin, Mark. Asia // The Cambridge Companion to Modern Russian Culture / Ed. by Nicholas Rzhevsky. Cambridge: Cambridge University Press, 2014. P. 65-93.

Bell, Duncan S. A. Mythscapes: memory, mythology, and national identities // British Journal of Sociology. 2003. Vol. 54. Issue 1 (March). P. 63-81.

Beller, Manfred. Perception, Image, Imagology // Imagology - The cultural construction and literary representations of national characters / Ed. by Manfred Beller and Joep Leerssen. Amsterdam: Rodopi, 2007. P. 3-16.

Boulding, Kenneth. The Image. New York: The University of Michigan Press, 1959. 175 p.

Brooks, Jeffrey. When Russia Learned to Read. Literacy and Popular Literature, 1861-1917. Evanston: Northwestern University Press, 2003. 450 p.

Crummey, Robert O. The Formation of Muscovy 1304-1613. London: Longman History of Russia, 1987. $275 \mathrm{p}$.

Fält, Olavi K. Introduction // Looking at the Other. Historical of Images in Theory and Practice / Ed. by Kari Alenius, Olavi K. Fält and Seija Jalagin. Oulu: Oulu University Press, 2007. P. 7-11.

Halperin, Charles. A Tatar Interpretation of the Battle of Kulikovo Field, 1380: Rustam Nabiev // Nationalities Papers. 2016. Vol. 44 (1). P. 4-19.

Halperin, Charles. Text and Textology: Salmina's dating of the Chronicle Tales about Dmitrii Donskoi // Slavonic and East European Review. 2001. Vol. 79. No. 2. P. 248-263.

Hastings, Adrian. The Construction of Nationhood. Ethnicity, Religion and Nationalism. Cambridge: Cambridge University Press, 2000. 235 p.

Heffernan, Thomas. Sacred Biography. Saints and their Biographers in the Middle Ages. New York: Oxford University Press, 1988. 333 p.

Hoppenbrouwers, Peter. Medieval peoples imagined // Imagology — The cultural construction and literary representations of national characters / Ed. by Manfred Beller and Joep Leerssen. Amsterdam: Rodopi, 2007. P. 45-62.

Ingham, Norman W. On Historical Truth and Hagiographical Truth: Saint Feodosii's Mother // Russian History/Histoire Russe. Vol. 18. No. 2 (Summer 1991). P. 127-141.

Lenhoff, Gail. Politics and Form in the Stepennaia Kniga // The Book of Royal Degrees and the Genesis of Russian Historical Consciousness / Ed. by Gail Lenhoff and Ann Kleimola. Bloomington: Slavica Publishers, 2011. P. 157-174.

Lotman, Yuriy Mikhaylovich; Uspenskiy, Boris Andreevich. The Role of Dual Models in the Dynamics of Russian Culture (Up to the Eighteenth Century) // Semiotics of Russian Culture / Ed. by Lotman, Yuriy Mikhaylovich; Uspenskiy, Boris Andreevich. Ann Arbor: University of Michigan, 1984. P. 3-35.

Lowenthal, David. Heritage Crusade and the Spoils of History. Cambridge: Cambridge University Press, 2009. $338 \mathrm{p}$.

Lowenthal, David. The Past is a Foreign Country. Cambridge: Cambridge University Press, 1985. 489 p. Miller, David B. Saint Sergius of Radonezh, His Trinity Monastery, and the Formation of the Russian Identity. DeKalb: Northern Illinois University Press, 2010. 374 p.

Miller, David B. Creating Legitimacy: Ritual, Ideology, and Power in Sixteenth Century Russia // Russian History/Histoire Russe. 1994. Vol. 21. No. 3. P. 289-315.

Mäki-Petäys, Mari. On the Applicability of Image Research to the Study of Medieval Hagiographies // Looking at the Other. Historical of Images in Theory and Practice / Ed. by Kari Alenius, Olavi K. Fält and Seija Jalagin. Oulu: Oulu University Press, 2007. P. 89-103.

Nora, Pierre. Between Memory and History // Les Lieux de Mémoire. Representations. 1989. Vol. 26. Spring. P. 7-24.

Ostrowski, Donald. Muscovy and the Mongols. Cross-Cultural Influences on the Steppe Frontier. Cambridge: Cambridge University Press, 2002. 329 p.

Parppei, Kati. The Battle of Kulikovo Refought — «The First National Feat». Leiden: Brill Academic Publishers, 2017. 258 p.

Parppei, Kati. «The Oldest One in Russia» - The Formation of the Historiographical Image of Valaam Monastery. Leiden: Brill Academic Publishers, 2011. 299 p. 
Picchio, Richard. The Impact of Ecclesiastic Culture on Old Russian Literary Techniques // Medieval Russian Culture / Ed. by Henrik Birnbaum and Michael S. Flier. Berkeley: University of California Press, 1984. P. 247-279.

Plokhy, Serhii. The Origins of the Slavic Nations. Premodern Identities in Russia, Ukraine, and Belarus. Cambridge: Cambridge University Press, 2006. 379 p.

Pospielovsky, Dimitry. Orthodox Church in the History of Russia. New York: St. Vladimir's Seminary Press, 1998. $413 \mathrm{p}$.

Ratz, David. The Study of Historical Images // Faravid. 2007. 31. P. 189-220.

Rock, Stella. Rasputin the New - Mythologies of Sanctity in Post-Soviet Russia // Nationalist myths and modern media: Contested identities in the age of globalization / Ed. by Jan Herman Brinks, Edward Timms and Stella Rock. London: I. B. Tauris, 2005. P. 257-270.

Sperling, Valerie. Making the Public Patriotic: Militarism and Anti-Militarism in Russia // Russian Nationalism and National Reassertion of Russia / Ed. by Marlène Laruelle. New York: Routledge, 2009. P. 218-271. The Official Site of Valaam Monastery (URL: https://valaam.ru/heritage/ (last visited — July 8, 2019)). Topolski, Jerzy. The Role of Logic and Aesthetics in Constructing Narrative Wholes in Historiography // History and Theory. 1999. Vol. 38. No 2. May. P. 198-210.

Information about the article

The article was written under the Academy Research Fellow funding granted by the Academy of Finland.

Author: Parppei, Kati Mari Johanna - Academy Research Fellow, Adjunct Professor, Department of Geographical and Historical Studies, University of Eastern Finland; Life Member, Clare Hall, University of Cambridge (UK), Scopus ID 36161985900, e-mail: kati.parppei@uef.fi

Title: Image Studies in Examining Shared Perceptions of the Past: Two Russian Cases

Summary: Historical image studies have been used successfully in analysing, for instance, representations of «otherness». Despite of its certain restrictions, the approach can also be used in studying phenomena that are more complex. In this article, two recent case studies, both concerning Russian historiography and the formation of national narratives, are shortly discussed in order to ponder upon the applicability of the method in examining collective perceptions of the past. The first case is about the formation of the historiographical image of the borderland monastery of Valaam. The second one examines the development of the collective ideas concerning the battle of Kulikovo (1380). It can be said that in the image formation of Valaam, the emphasis is on spatiality, religion and contested frontier, whilst in the case of Kulikovo imagery, the ideas of temporality, national significance and active, unified resistance prevail. What is common for both case studies, however, is that the formation of the imagery has been intertwined with contemporary political issues of each given time. The process has had a full support of the power structures. Also, there is strong undercurrent of National Romanticist thinking connected to both of the cases. Both of the imageries have been formed anachronistically, in hindsight. Especially in the case of Kulikovo this phenomenon has a central role: the idea of the medieval battle as a crucial turning point is a prime example of explaining history in the light of contemporary knowledge and the prevailing ideological undercurrents. In both cases it is possible to analyze and trace the formation of separate images of certain scenes, turns and figures, and on the other hand, examine them as a whole imagery.

Keywords: image, historiography, nationalism, identities, myths, narratives

\section{References:}

Amel'kin, Andrey Olegovich; Seleznev, Yuriy Vasilyevich. Kulikovskaya bitva v svidetel'stvakh sovremennikov i pamyati potomkov [Battle of Kulikovo in the Testimony of the Contemporaries and the Memory of the Posterity]. Moscow: Kvadriga Publ., 2011. 414 p. (in Russian).

Assmann, Jan. Collective Memory and Cultural Identity, in New German Critique. 1995. No. 65 (SpringSummer). Pp. 125-133.

Azbelev, Sergey Nikolaevich. Kulikovskaya pobeda v narodnoy pamyati [Victory of Kulikovo in the Memory of the People]. St. Petersburg: Dmitriy Bulanin Publ., 2011. 312 p. (in Russian).

Bassin, Mark. Asia, in Rzhevsky, Nicholas (ed.). The Cambridge Companion to Modern Russian Culture. Cambridge: Cambridge University Press, 2014. Pp. 65-93.

Bell, Duncan S. A. Mythscapes: memory, mythology, and national identities, in British Journal of Sociology. 2003. Vol. 54. Issue 1 (March). Pp. 63-81. 
Beller, Manfred. Perception, Image, Imagology, in Beller, Manfred; Leerssen, Joep (eds). Imagology — The cultural construction and literary representations of national characters. Amsterdam: Rodopi Publ., 2007. Pp. 3-16.

Bobrov, Aleksandr Grigoryevich. Novgorodskie letopisi XV veka [Novgorod Chronicles of the $15^{\text {th }}$ Century]. St. Petersburg: Dmitriy Bulanin Publ., 2001. 287 p. (in Russian).

Boulding, Kenneth. The Image. New York: The University of Michigan Press, 1959. 175 p.

Brooks, Jeffrey. When Russia Learned to Read. Literacy and Popular Literature, 1861-1917. Evanston: Northwestern University Press, 2003. 450 p.

Crummey, Robert O. The Formation of Muscovy 1304-1613. London: Longman History of Russia Publ., 1987. $275 \mathrm{p}$.

Fält, Olavi K. Introduction, in Alenius, Kari; Fält, Olavi K.; Jalagin, Seija (eds). Looking at the Other. Historical of Images in Theory and Practice. Oulu: Oulu University Press, 2007. Pp. 7-11.

Halperin, Charles. A Tatar Interpretation of the Battle of Kulikovo Field, 1380: Rustam Nabiev, in Nationalities Papers. 2016. Vol. 44 (1). Pp. 4-19.

Halperin, Charles. Text and Textology: Salmina's dating of the Chronicle Tales about Dmitrii Donskoi, in Slavonic and East European Review. 2001. Vol. 79. No. 2. Pp. 248-263.

Hastings, Adrian. The Construction of Nationhood. Ethnicity, Religion and Nationalism. Cambridge: Cambridge University Press, 2000. 235 p.

Heffernan, Thomas. Sacred Biography. Saints and their Biographers in the Middle Ages. New York: Oxford University Press, 1988. 333 p.

Hoppenbrouwers, Peter. Medieval peoples imagined, in Beller, Manfred; Leerssen, Joep (eds). Imagology The cultural construction and literary representations of national characters. Amsterdam: Rodopi Publ., 2007. Pp. 45-62.

Ingham, Norman W. On Historical Truth and Hagiographical Truth: Saint Feodosii's Mother, in Russian History/Histoire Russe. 1991. Vol. 18. No. 2 (Summer). Pp. 127-141.

Kloss, Boris Mikhaylovich. Nikonovskiy svod i russkie letopisi XVI-XVII vekov [Nikon Chronicle and Russian Chronicles of $16^{\text {th }}$ and $17^{\text {th }}$ centuries]. Moscow: Nauka Publ., 1980. 336 p. (in Russian).

Kuchin, P. Kulikovskaya bitva. Biblioteka krasnoarmeytsa [The Battle of Kulikovo. The Library of the Red Army]. Moscow: Voenizdat Publ., 1939. 32 p. (in Russian).

Lenhoff, Gail. Politics and Form in the Stepennaia Kniga, in Lenhoff, Gail; Kleimola, Ann (eds). The Book of Royal Degrees and the Genesis of Russian Historical Consciousness. Bloomington: Slavica Publishers, 2011. Pp. 157-174.

Lisovoy, Nikolay Nikolaevich. Vosemnadtsatiy vek v istorii russkogo monashestva [18th Century in the History of Russian Monasticism], in Sinitsyna, Nina Vasilyevna (ed.). Monashestvo i monastyri v Rossii XI-XX veka: Istoricheskie ocherki. Moscow: Nauka Publ., 2002. Pp. 186-222. (in Russian).

Lotman, Yuriy Mikhaylovich; Uspenskiy, Boris Andreevich. The Role of Dual Models in the Dynamics of Russian Culture (Up to the Eighteenth Century), in Lotman, Yuriy Mikhaylovich; Uspenskiy, Boris Andreevich (eds). Semiotics of Russian Culture. Ann Arbor: University of Michigan, 1984. Pp. 3-35.

Lowenthal, David. Heritage Crusade and the Spoils of History. Cambridge: Cambridge University Press, 2009. 338 p.

Lowenthal, David. The Past is a Foreign Country. Cambridge: Cambridge University Press, 1985. 489 p. Mäki-Petäys, Mari. On the Applicability of Image Research to the Study of Medieval Hagiographies // Alenius, Kari; Fält, Olavi K.; Jalagin, Seija (eds). Looking at the Other. Historical of Images in Theory and Practice. Oulu: Oulu University Press, 2007. Pp. 89-103.

Miller, David B. Creating Legitimacy: Ritual, Ideology, and Power in Sixteenth Century Russia, in Russian History/Histoire Russe. 1994. Vol. 21. No. 3. Pp. 289-315.

Miller, David B. Saint Sergius of Radonezh, His Trinity Monastery, and the Formation of the Russian Identity. DeKalb: Northern Illinois University Press, 2010. 374 p.

Nora, Pierre. Between Memory and History, in Les Lieux de Mémoire. Representations. 1989. Vol. 26. Spring. Pp. 7-24.

Okhotina-Lind, Natalya Aleksandrovna. Skazanie o Valaamskom monastyre [The Tale of the Monastery of Valaam]. St. Petersburg: Glagol Publ., 1996. 246 p. (in Russian).

Onufriy, ierodiakon (Makhanov). Prichal molitv uyedinennykh. Valaamskiy monastyr'i ego nebesnye pokroviteli prepodobnye Sergiy i German [Quay for Secluded Prayers. The Monastery of Valaam and its Heavenly Patrons, Venerable Sergei and German]. St. Petersburg: «Tsarskoe Delo» Publ., 2005. 738 p. (in Russian). 
Ostrowski, Donald. Muscovy and the Mongols. Cross-Cultural Influences on the Steppe Frontier. Cambridge: Cambridge University Press, 2002. 329 p.

Parppei, Kati. «The Oldest One in Russia» - The Formation of the Historiographical Image of Valaam Monastery. Leiden: Brill Academic Publishers, 2011. 299 p.

Parppei, Kati. The Battle of Kulikovo Refought — «The First National Feat». Leiden: Brill Academic Publishers, 2017. $258 \mathrm{p}$.

Picchio, Richard. The Impact of Ecclesiastic Culture on Old Russian Literary Techniques, in Birnbaum, Henrik; Flier, Michael S. (eds). Medieval Russian Culture. Berkeley: University of California Press, 1984. Pp. 247-279.

Plokhy, Serhii. The Origins of the Slavic Nations. Premodern Identities in Russia, Ukraine, and Belarus. Cambridge: Cambridge University Press, 2006. 379 p.

Pospielovsky, Dimitry. Orthodox Church in the History of Russia. New York: St. Vladimir's Seminary Press, 1998. $413 \mathrm{p}$.

Pushkarev, Lev Nikitovich; Sidorova, L. P. Povesti o Kulikovskoy bitve v russkoy lubochnoy kartinke i knizhke XIX - nachala XX veka [Tales of the Battle of Kulikovo in Russian lubok images and booklets from the $19^{\text {th }}$ century to the beginning of the $20^{\text {th }}$ century], in Robinson, Andrey Nikolaevich (ed.). Kulikovskaya bitva v literature i iskusstve. Moscow: Nauka Publ., 1980. Pp. 129-153 (in Russian).

Ratz, David. The Study of Historical Images, in Faravid. 2007. 31. Pp. 189-220.

Robinson, Andrey Nikolaevich (ed.). Kulikovskaya bitva v literature i iskusstve [Battle of Kulikovo in the Literature and Art]. Moscow: Nauka Publ., 1980. 288 p. (in Russian).

Rock, Stella. Rasputin the New - Mythologies of Sanctity in Post-Soviet Russia, in Brinks, Jan Herman; Timms, Edward; Rock, Stella (eds). Nationalist myths and modern media: Contested identities in the age of globalization. London: I. B. Tauris Publ., 2005. Pp. 257-270.

Rostovtsev, Evgeniy Anatolyevich; Sosnitskiy, Dmitriy Aleksandrovich. «Kulikovskiy plen»: obraz Dmitriya Donskogo v natsional'noy istoricheskoy pamyati ["The Capture of Kulikovo": the Image of Dmitrii Donskoi in the National Historical Memory], in Quaestio Rossica. Vol. 5. 2017. No. 4. Pp. 1149-1163. (in Russian).

Rybakov, Boris Aleksandrovich; Kuchkin, Vladimir Andreevich. Pamyatniki Kulikovskogo tsikla [Memorials of Kulikovo]. St. Petersburg: Russko-baltiyskiy informatsionnyi tsentr BLITs Publ., 1998. 412 p. (in Russian). Sakharov, Andrey Nikolaevich. Istoriya Rossii s drevneyshikh vremen do kontsa XVI veka. Akademicheskiy shkolniy uchebnik [History of Russia from the Ancient Times to the End of the $16^{\text {th }}$ Century]. Moscow: Prosveshchenie Publ., 2013. 255 p. (in Russian).

Salmina, Marina Alekseevna. K voprosu o vremeni i obstoyatelstvakh sozdaniya «Skazaniya o Mamaevom poboishche» [To the Question of the Dating and Circumstances of the Production of the "Tale of the Rout of Mamai"], in Trudy otdela drevnerusskoy literatury. Vol. 56. 2004. Pp. 251-274. (in Russian).

Sperling, Valerie. Making the Public Patriotic: Militarism and Anti-Militarism in Russia, in Laruelle, Marlène (ed.). Russian Nationalism and National Reassertion of Russia. New York: Routledge Publ., 2009. Pp. 218-271. Spiridonov, Andrey Mikhaylovich; Yarovoy, Oleg Arkadyevich. Valaam: ot apostola Andreya do igumena Innokentiya [Valaam: from Apostle Andrew to Igumen Innokentiy]. Moscow: Prometey Publ., 1991. 125 p. (in Russian).

Topolski, Jerzy. The Role of Logic and Aesthetics in Constructing Narrative Wholes in Historiography, in History and Theory. 1999. Vol. 38. Issue 2. May. Pp. 198-210. 